\title{
NEPHRO-PROTECTIVE EFFECT OF THE INDONESIAN PROPOLIS EXTRACT ON UNILATERAL RENAL URETER OBSTRUCTIVE DAMAGE
}

\author{
Agung Susanto1,2), Bambang Purwanto'), Ambar Mudigdo3), Suroto4) \\ 1)Faculty of Medicine,Universitas Sebelas Maret \\ 2)Department of Internal Medicine, Dr.Moewardi Hospital \\ 3)Department of Anatomical Pathology, Dr. Moewardi Hospital \\ 4)Department of Neurology, Dr. Moewardi Hospital
}

\begin{abstract}
Background: Ureter obstruction can cause permanent renal damage. In theory, the Indonesian propolis extract (IPE) may play an important role as an antioxidant and anti-inflammatory agent. This study aimed to determine the nephroprotective effect of IPE in reducing interstitial fibrosis, systolic blood pressure (SBP) and increasing body weight in mice with unilateral ureteric obstruction (UUO).

Subjects and Method: This study was a quasi experiment. A total sample of 32 mice was allocated into four groups: (1) Mice without UUO; (2) Mice with UUO; (3) Mice with UUO privided with IPE (orally 50mg/ kgBW); (4) Mice with UUO provided with IPE (orally 100mg/ kgBW). After 30 days of intervention, the mice were killed for interstitial fibrosis analysis. Mean differences in body weight, sistolic blood pressure (SBP), and interstitial fibrosis were tested by one way ANNOVA and Kruskal Wallis.

Results: Interstitial fibrosis and SBP were higher in group 2 than group 1 resulting from UUO $(\mathrm{p}<0.05)$. Body weight was lower in group 2 than group 1 resulting from UUO $(\mathrm{p}<0.05)$. Interstitial fibrosis and SBP were lower in both group 3 and 4 than group $2(\mathrm{p}<0.05)$, indicating that IPE was effective in reducing interstitial fibrosis and SBP. Body weight was higher in group 3 and 4 than group $2(\mathrm{p}<0.05)$, indicating that IPE was effective in increasing body weight.
\end{abstract}

Conclusion: IPE can effectively reduce interstitial fibrosis and SBP in mice, and increase body weight.

Keywords: renal ureter obstructive damage, Indonesian propolis extract

Correspondence:

Agung Susanto.Faculty of Medicine, Universitas Sebelas Maret, Jl. Ir.Sutami No. 36 A, 57126, Surakarta, Central Java.

Mid-International Conference on Public Health, Best Western Premier Hotel, Solo, Indonesia, 18-19 April 2018 | 240

https://doi.org/10.26911/mid.icph.2018.05.02 